\title{
Bantuan Sosial bagi Warga Lanjut Usia di Masa Pandemi
}

\author{
Sari Handayani ${ }^{1}$
}

\begin{abstract}
Abstrak
Penduduk lanjut usia termasuk dalam kelompok rentan di masa pandemi COVID-19. Tujuan tulisan ini adalah untuk mengidentifikasi peran pemerintah baik tingkat pusat maupun daerah dalam pemberian bantuan sosial bagi lansia. Data penelitian didapatkan dari open source sejak bulan Maret hingga Juli 2020. Ditemukan bahwa pada level pusat, Kementerian Sosial dan Kementerian Pemberdayaan Perempuan dan Perlindungan Anak, serta pada level daerah, Pemerintah Provinsi DKI Jakarta dan Jawa Timur, telah menyediakan bantuan sosial yang menyasar lansia di masa pandemi. Program bantuan ini kemudian dianalisis menggunakan konsep familisasi dan defamilisasi. Beberapa lansia sebelum masa pandemi masih mampu bekerja dan memenuhi kebutuhan hidup sehari-hari tanpa bergantung pada keluarga (defamilisasi). Namun, selama pandemi, lansia tersebut harus bergantung kembali kepada keluarga (familisasi) karena terbatas untuk bekerja di luar rumah dan atau tidak memiliki dana pensiun. Dapat disimpulkan bahwa bantuan sosial dari pemerintah bagi lansia selama masa pendemi sangat diperlukan untuk mengurangi risikorisiko defamilisasi.
\end{abstract}

Kata kunci: bantuan sosial; lanjut usia; COVID-19; familisasi; defamilisasi

\begin{abstract}
Elderly are included in the vulnerable group during the COVID-19 pandemic. This paper aims to identify the role of government at both the central and regional levels in providing social assistance for the elderly during the pandemic. This study utilizes an open-source obtained from March to July 2020. It was found that at the central level and at the regional level, have provided social assistance. This assistance is then analyzed using the concept of familization and defamilization. Some elderly before the pandemic were still able to work and fulfill their daily needs without depending on family (defamilization). However, due to the pandemic, the elderly had to depend on their families (familization) because they are limited to working outside the home and do not have a pension fund. It can be concluded that social assistance from the government during the pandemic is very much needed to reduce the risk of defamilization.
\end{abstract}

Keywords: social assistance; elderly; COVID-19; familization; defamilization

\section{Pendahuluan}

Penduduk lanjut usia (lansia) merupakan salah satu kelompok penduduk yang dinilai rentan terhadap penyebaran virus COVID-19. Pemerintah menghimbau masyarakat untuk menjaga dan memberi perhatian lebih pada lansia. Upaya pencegahan aktivitas mudik dipandang sebagai bentuk kepedulian terhadap lansia agar terhindar dari virus COVID-19. Lansia menjadi kelompok yang rentan terabaikan pada masa bencana, misalnya kebutuhan-kebutuhan spesifik seperti kebutuhan istirahat, asupan gizi, dan akses dalam menjalankan aktivitas seharihari (Lindawati, 2019). Hal tersebut diperparah dengan adanya ketimpangan global, yaitu hampir setengah dari populasi lansia di negara berkembang tidak memiliki akses pelayanan kesehatan (United Nations, 2020).
Berdasarkan data dari Satgas COVID-19 Indonesia per tanggal 26 Agustus 2020, kematian penduduk tertinggi akibat COVID-19 berasal dari kelompok umur 46-59 tahun, yaitu sebanyak 39,9\% (Gugus Tugas Percepatan Penanganan COVID-19, 2020a). Selain itu, kelompok umur $\geq 60$ tahun hanya memiliki selisih 1,6\% dari kelompok umur dengan korban terbanyak, yakni 38,3\% dari total penduduk Indonesia yang meninggal karena COVID-19. Dari data tersebut, tergambar bahwa lansia menjadi salah satu kelompok umur dengan risiko tinggi terpapar virus COVID-19.

Berdasarkan data Statistik Penduduk Lanjut Usia tahun 2019, dari 100 lansia terdapat 26-27 lansia yang sakit (BPS, 2019). Angka kesakitan lansia kemungkinan besar mengalami peningkatan kembali di tahun 2020 karena

\footnotetext{
${ }^{1}$ Departemen Pembangunan Sosial dan Kesejahteraan, Fakultas Ilmu Sosial dan Ilmu Politik, Universitas Gadjah Mada (email korespondensi: sarihandayani@ugm.ac.id)
} 
Gambar 1

Angka Kesakitan Lansia tahun 2011-2019 (\%)

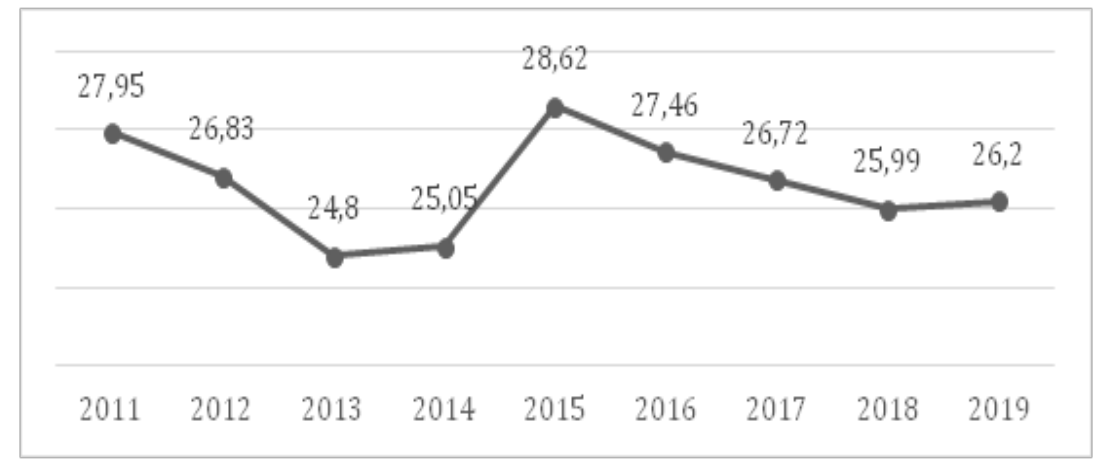

Sumber: Badan Pusat Statistik (BPS), 2011-2019

Gambar 2

Rumah Tangga Lansia yang Memiliki Jaminan Kesehatan Tahun 2012 - 2019 (\%)

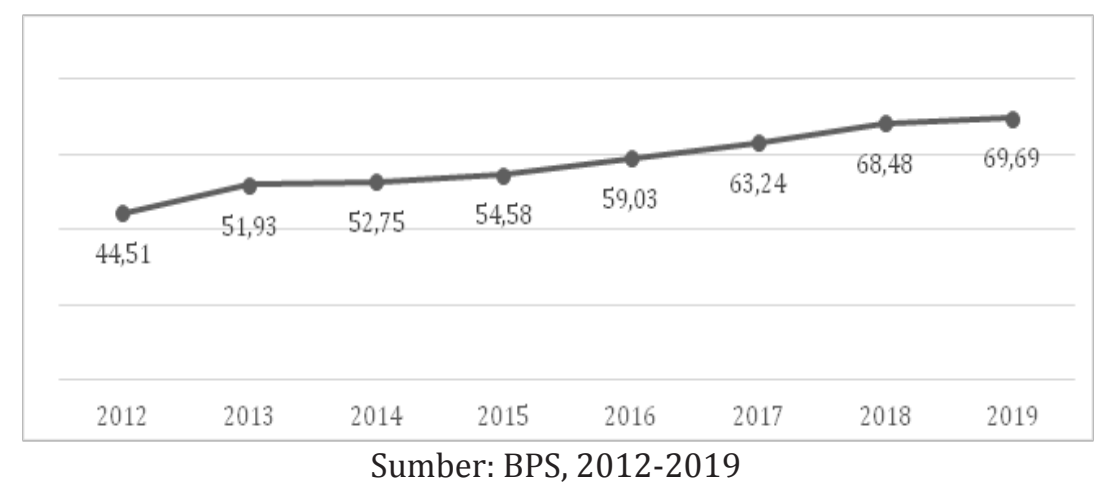

penyebaran virus COVID-19 yang terjadi pada tahun ini (lihat Gambar 1). Kondisi lain menunjukkan bahwa tidak seluruh lansia di Indonesia memiliki kesempatan yang sama dalam mengakses jaminan kesehatan karena terdapat 30,31\% atau satu dari tiga lansia yang belum memiliki jaminan kesehatan (BPS, 2019). Jumlah rumah tangga lansia yang memiliki jaminan kesehatan sejak tahun 2012 hingga 2019 selalu menunjukkan tren kenaikan (lihat Gambar 2). Kondisi tersebut menunjukkan bahwa masih banyak rumah tangga lansia yang belum memiliki jaminan kesehatan, baik yang dibiayai sendiri maupun dengan bantuan dari pemerintah. Jaminan kesehatan lansia di masa pandemi harus lebih diperhatikan, salah satunya dengan penyediaan pelayanan kesehatan yang ramah lansia dan dapat diakses oleh seluruh lansia.

Salah satu bentuk perlindungan sosial bagi lansia adalah bantuan sosial. Indonesia memiliki skema Bantuan Pangan Non Tunai (BPNT) sebagai hasil pengembangan dari skema sebelumnya, yaitu bantuan sosial beras sejahtera (Bansos Rastra). BPNT adalah program pemerintah terkait bantuan sosial pangan yang diberikan dalam bentuk nontunai kepada kelompok penerima manfaat setiap bulan. Bantuan tersebut diberikan melalui dana elektronik yang dapat digunakan untuk membeli bahan makanan di warung yang sudah bekerja sama dengan program ini (Pusdatin Kesos, 2019).

Lansia juga menjadi salah satu penerima manfaat dalam Program Keluarga Harapan (PKH). Sebelumnya, jadwal pemberian dana kepada lansia adalah setiap tiga bulan sekali, pada masa pandemi berubah menjadi sebulan sekali. Lansia yang berusia di atas 70 tahun mendapatkan bantuan dana tunai sejumlah Rp200.000 per bulan (Kementerian Sosial RI, 2020m). Pada tahun 2017, PKH dan bantuan sosial untuk lansia dalam Program Asistensi Sosial Lanjut Usia Terlantar (ASLUT) hanya diberikan kepada sekitar 150.000 orang dari 23,4 juta lansia (Tim Nasional Percepatan Penanggulangan Kemiskinan, 2018). Sejak tahun 2020, diputuskan bahwa lansia yang mendapat 
Gambar 3

Rasio Ketergantungan Lansia tahun 2010-2019 (\%)

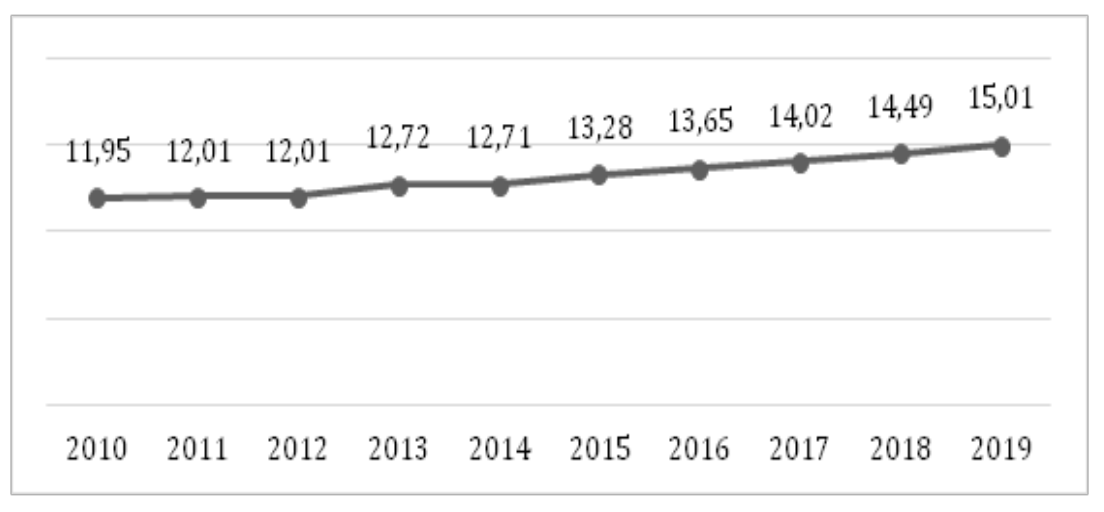

Sumber: BPS, 2010-2019

bantuan PKH adalah lansia berusia di atas 70 tahun dari sebelumnya di atas 60 tahun. Merujuk pada jumlah lansia yang ada di Indonesia pada tahun 2019, jumlah lansia tertinggi adalah lansia muda dengan rentang umur dari 60-69 tahun, yaitu sebanyak 63,82\% (BPS, 2019).

Jenis bantuan sosial lainnya adalah Program Rehabilitasi Sosial Lanjut Usia (PROGRESS LU). PROGRESS LU terdiri dari bantuan bagi lanjut usia (bantuan uang tunai), perawatan sosial (pendampingan keluarga lanjut usia oleh Pendamping dari LKS-LU), dukungan keluarga (bantuan uang tunai kepada anggota keluarga untuk merawat lansia), dan terapi sosial (intervensi rehabilitasi sosial) (Parjono, 2020). Sebagai contoh, PROGRES-LU pada tahun 2020 telah terdistribusi bagi 8.900 lanjut usia yang berada di Provinsi Sulawesi Selatan, Sulawesi Barat, Kalimantan Selatan, Kalimantan Barat, Kalimantan Tengah, Kalimantan Timur, Kalimantan Utara, NTB, NTT, dan Bali (Kementerian Sosial RI, 2020e).

Sebelum pandemi COVID-19, sudah terjadi peningkatan rasio ketergatungan lansia terhadap penduduk produktif. Pada tahun 2010, rasionya adalah 11,95 dan naik menjadi 15,01 pada 2019 (lihat Gambar 3) yang berarti setiap 100 orang penduduk usia produktif (15-59 tahun) harus menanggung 15 orang penduduk lansia (BPS, 2019). Angka ini diproyeksikan meningkat pada tahun 2020 tidak hanya akibat penambahan jumlah lansia, tetapi juga akibat pandemi COVID-19. Kondisi ini menjadi pemicu naiknya rasio ketergantungan lansia terhadap penduduk produktif. Lansia yang bergantung pada keluarga adalah lansia yang tidak bekerja, tidak memiliki jaminan pensiun, dan juga terbatas dalam mengakses perlindungan sosial dari pemerintah. Maka dari itu, ada lansia yang menggantungkan hidup pada keluarga, baik anak maupun cucu (generasi ketiga). Kondisi ini pada akhirnya berpotensi memberikan beban baik sosial maupun ekonomi kepada keluarga yang ditumpanginya.

\section{Kerangka Teori \\ Kebijakan Sosial untuk Lansia di Indonesia}

Fenomena pertambahan penduduk lansia dihadapi oleh negara-negara maju dan berkembang. Setiap negara harus bersiap menyesuaikan kebijakan sosial dengan mempertimbangkan komposisi jumlah pendudukberdasar usia. Pada tahun 2050,Jepang diproyeksikan memiliki 40\% penduduk lansia (Minchung \& Tomoaki, 2017). Kebijakan sosial di Jepang menunjukkan upaya serius negara untuk menyambut pertumbuhan penduduk lanjut usia. Pada tahun 2000, Jepang menerapkan Long Term Care Insurance (LTCI) yang ditujukan bagi seluruh penduduk berusia 65 tahun ke atas (Yong \& Saito, 2011). LTCI bertujuan untuk membagi tanggung jawab perawatan lansia sehingga tidak lagi dibebankan hanya kepada keluarga dan negara, tetapi juga komunitas secara luas. Selanjutnya, sejak tahun 2006, Jepang memiliki skema pelayanan kesehatan bagi lansia yang melibatkan peran komunitas dan swasta yang dikenal dengan The Communitybased Integrated Care System (CbICS) (Tsutsui, 2014). Pelaksanaan sistem tersebut didukung unsur self-help, mutual aid, social solidarity care, dan government care (Sudo, Kobayashi, Noda, Fukuda, \& Takahashi, 2018). Dua kebijakan yang diterapkan oleh Jepang tersebut bertujuan untuk 
mengurangi beban keluarga dalam merawat lansia. Tingginya jumlah penduduk lansia menimbulkan konsekuensi berupa tingginya angka ketergantungan pada penduduk usia produktif. Lansia berpeluang lebih besar untuk mengalami kemiskinan daripada penduduk usia poduktif.

Kebijakan pemerintah yang mengatur kesejahteraan lanjut usia tertuang pada Undang-Undang Republik Indonesia Nomor 13 Tahun 1998. Definisi lansia pada UU ini adalah seseorang yang telah mencapai usia 60 tahun ke atas. Selain itu, dalam UU ini lansia dibedakan menjadi dua, yaitu lansia potensial dan tidak potensial. Lansia potensial adalah lansia yang masih mampu melakukan pekerjaan dan/atau kegiatan yang dapat menghasilkan barang dan/atau jasa. Lansia tidak potensial adalah lansia yang tidak berdaya mencari nafkah sehingga hidupnya bergantung pada bantuan orang lain. Kategorisasi ini membedakan lansia produktif dengan lansia tidak produktif. Konsekuensi selanjutnya adalah perbedaan hak yang akan diterima oleh masing-masing kategori. Lansia potensial tidak berhak mendapatkan perlindungan sosial, sedangkan lansia tidak potensial tidak berhak mendapatkan pelayanan kesempatan kerja, pelayanan pendidikan dan pelatihan, serta bantuan sosial.

Berdasarkan hal di atas, perlu dilihat definisi perlindungan sosial dan bantuan sosial pada UU tersebut. Perlindungan sosial didefinisikan sebagai upaya pemerintah dan/atau masyarakat untuk memberikan kemudahan pelayanan bagi lanjut usia tidak potensial agar dapat mewujudkan dan menikmati taraf hidup yang wajar. Pemberian perlindungan sosial ini diselenggarakan baik di dalam maupun di luar panti. Di sisi lain, bantuan sosial didefinisikan sebagai upaya pemberian bantuan yang bersifat tidak tetap agar lanjut usia potensial dapat meningkatkan taraf kesejahteraan sosialnya. Bentuk bantuan sosial ini berupa material, finansial, fasilitas pelayanan, dan informasi yang mendorong tumbuhnya kemandirian. Hal ini juga tertuang pada Peraturan Pemerintah Republik Indonesia Nomor 43 Tahun 2004 Tentang Pelaksanaan Upaya Peningkatan Kesejahteraan Sosial Lanjut Usia. UU Nomor 13 Tahun 1998 Tentang Kesejahteraan Lansia yang memasukkan pemberian pelayanan kesehatan, namun harapannya tidak hanya pemberian pelayanan kesehatan secara fisik, tetapi juga mental, yaitu perhatian khusus untuk kondisi psikologis lansia. Lansia tidak hanya mengalami berbagai permasalahan berupa ekonomi, sosial, dan kesehatan, tetapi juga permasalahan psikis (Kementerian Koordinator Bidang Pembangunan Manusia dan Kebudayaan RI, 2015).

Selanjutnya, terdapat Peraturan Menteri Sosial Republik Indonesia Nomor 12 Tahun 2013 Tentang Program Asistensi Lanjut Usia Terlantar. Lanjut usia terlantar adalah lanjut usia yang mengalami ketelantaran, tidak potensial, tidak memiliki dana pensiun, asset, atau tabungan yang cukup sehingga mereka tidak dapat memenuhi kebutuhan dasar hidupnya dengan layak. Dalam peraturan ini, disebutkan bahwa lansia tidak potensial berhak menerima bantuan karena termasuk dalam kategori lansia terlantar. Selain itu, bantuan ini hanya dapat memenuhi kebutuhan dasar hidup dari lansia terlantar sehingga tetap diperlukan intervensi lain, seperti dari pemerintah daerah, keluarga, kelompok masyarakat, dan perusahaan.

Presiden menetapkan Penyebaran COVID-19 sebagai bencana nasional pada 13 April 2020 (Sekretariat Kabinet RI, 2020). Pada UndangUndang Republik Indonesia Nomor 24 tahun 2007 tentang Penanggulangan Bencana, Pasal 26 Ayat 1 Huruf a, disebutkan bahwa setiap orang berhak mendapatkan perlindungan sosial dan rasa aman, khususnya kelompok masyarakat rentan bencana. Selanjutnya, pada Pasal 55 Ayat 1 disebutkan perlindungan terhadap kelompok rentan dilakukan dengan memberikan prioritas kepada kelompok rentan berupa penyelamatan, evakuasi, pengamanan, pelayanan kesehatan, dan psikososial. Pada Pasal 55 Ayat 2 juga disebutkan bahwa yang termasuk dalam kelompok rentan salah satunya adalah orang lanjut usia (lansia).

Dari beberapa kebijakan sosial yang berkaitan dengan perlindungan sosial lansia, terdapat tuntutan untuk segera merevisi Undang-Undang Republik Indonesia Nomor 13 Tahun 1998 Tentang Kesejahteraan Lanjut Usia. Hal tersebut dikarenakan UU ini merupakan rujukan dari lahirnya kebijakan sosial yang berkaitan dengan lansia. Beberapa perbaikan yang dapat dilakukan adalah dengan merespon perubahan konteks yang telah terjadi lebih dari dua dekade (Hastuti, Darwin, Sukamdi, \& Hadna, 2018). Selain itu, terdapat evaluasi dari implementasi kebijakan lanjut usia terlantar yang juga telah diatur dalam Peraturan Menteri Sosial Republik Indonesia Nomor 12 Tahun 
2013 Tentang Program Asistensi Lanjut Usia Terlantar (ASLUT). Kebijakan tersebut dinilai belum mendukung peningkatan kesejahteraan lansia terlantar secara nyata, cakupan konteks kebijakan masih parsial, dan belum terintegrasi dalam program-program di tingkat daerah, serta keterbatasan dalam ketersediaan daya dukung berupasumber daya manusia, anggaran, infrastruktur, lingkungan sosial dan budaya (Yanuardi, Fitriana, \& Ahdiyana, 2017).

\section{Defamilisasi dan Familisasi Lansia}

Taylor-Gooby dalam Chau \& Yu (2019) melihat defamilisasi sebagai sejauh mana negara dapat mengurangi ketergantungan perempuan pada keluarga dan memfasilitasi kemandirian ekonominya. Selain itu, terdapat anggapan bahwa pemerintah perlu untuk menyediakan beberapa hal seperti layanan perawatan publik untuk anak-anak dan orang tua, dana pensiun, dan tunjangan pengasuh dalam membantu masyarakat menangani risiko defamilisasi dan familisasi (Israle \& Spannagel, 2018). Esping-Andersen dalam Chau \& Yu (2019) mendefinisikan defamilisasi sebagai sejauh mana kesejahteraan dan tanggung jawab mengurus rumah tangga disediakan baik melalui penyediaan kesejahteraan oleh negara maupun oleh swasta. Berkaitan dengan hal ini, individu dibebaskan dalam keterlibatannya untuk merawat keluarga atau juga nantinya sebagai penerima perawatan itu sendiri, misalnya ketika sudah lansia dan membutuhkan perawatan harian. Akan tetapi, kondisi yang dapat memilih untuk mendapatkan perawatan dari swasta menjadi pilihan yang tidak dapat diakses oleh seluruh lansia di Indonesia. Penyebabnya adalah kondisi kecukupan ekonomi yang berbedabeda untuk membiayai perawatan tersebut. Perawatan lansia membutuhkan anggaran untuk jangka panjang. Jika menggantungkan pada pelayanan dari swasta, perlu dipastikan kecukupan dana agar perawatan terhadap lansia dapat terus dilakukan.

Pendapat serupa terkait konsep defamilisasi adalah deskripsi wewenang negara atas hakhak sosial individu yang mengurangi tanggung jawab dan ketergantungan terhadap keluarga (Saraceno \& Keck, 2010). Kebijakan familisasi dan defamilisasi tidak selalu bertentangan. Bahkan, beberapa negara di Eropa menunjukkan bahwa mereka terintegrasi dan bisa saling melengkapi (dukungan publik atas kewajiban antargenerasi). Kebijakan defamilisasi juga dapat dipahami sebagai ketentuan negara (kebijakan dan peraturan sosial) yang mengurangi tanggung jawab dan ketergantungan terhadap perawatan dan keuangan antaranggota keluarga (Lohmann \& Zagel, 2016). Di sisi lain, kebijakan familisasi mencakup semua pembayaran tunai yang mendukung perawatan keluarga di rumah (untuk kebutuhan hidup, yangtermasuk di dalamnya layanan home care). Yang termasuk dalam kebijakan familisasi adalah kewajiban anak untuk mengasuh orang tua.

Perawatan lansia di Korea secara tradisional dikaitkan dengan tanggung jawab anak tertua dan istrinya (Shin, 2013). Kondisi ini juga didukung oleh familisasi, yaitu norma dan lembaga yang didirikan atas prinsip kesinambungan keluarga (adanya ikatan darah) dan difungsikan untuk mendistribusikan tanggung jawab perawatan lansia ke lingkungan sosial seperti keluarga, kerabat, dan komunitas lokal. Di sisi lain, undang-undang tentang Asuransi Perawatan Jangka Panjang mengakui tanggung jawab negara dalam memberikan perawatan dan hak-hak sosial penerima perawatan. Sebelum berlakunya UU tersebut, lembaga perawatan hanya diperuntukkan bagi kelompok berpenghasilan rendah, sedangkan yang lain harus menanggung biayanya masing-masing.

\section{Risiko Defamilisasi bagi Lansia pada Masa Pandemi}

Kondisi ketika lansia tidak bergantung kepada bantuan keluarga di masa pandemi akan dihadapkan pada posisi yang tidak menguntungkan terkait dengan kesempatan kerja. Pada masa krisis, para lansia yang bekerja berpeluang besar untuk dipensiunkan secara dini (Johnson \& Butrica, 2012). Hal tersebut juga berkaitan dengan adanya pembatasan berkegiatan di luar rumah. Diskriminasi usia juga dihadapi oleh para lansia yang mampu bekerja dan ingin mencari kerja. Banyaknya pelamar kerja usia produktif di pasar kerja membuat pemberi kerja dapat menerapkan kriteria seleksi dengan memperhatikan preferensi usia (Neumark \& Button, 2014).

Lansia yang memasuki masa pensiun merasa butuh untuk kembali bekerja. Disamping itu, para lansia yang tetap bekerja merasa ingin dan juga butuh untuk tetap bekerja. Namun, pada masa pandemi ini, para lansia seakan terpaksa harus kembali bekerja untuk 
memenuhi kebutuhan tambahan yang muncul dalam rangka mencegah penyebaran virus COVID-19. Usaha yang dapat dilakukan adalah dengan menciptakan lingkungan kerja yang sesuai dengan protokol kesehatan dan kebijakan yang mengaturnya (Morrow-Howell, Galucia, \& Swinford, 2020). Hal tersebut penting dilakukan pada masa pandemi. Lapangan kerja ini harus mencegah terjadinya diskriminasi usia yang dapat membuat pekerja lansia menghadapi risiko seperti depresi, penurunan kesehatan, dan ketidakpuasan dalam bekerja (Marchiondo, Gonzales, \& Williams, 2019).

Hal-hal tersebut memiliki risiko berupa paparan virus kepada lansiayang mampu bekerja. Tidak semua pekerja lansia mendapatkan kesempatan untuk bekerja dari rumah selama masa pandemi. Selain itu, para lansia yang bekerja secara informal sangat bergantung pada kehadiran mereka di tempat kerja yang berdampak pada upah yang akan diterima (Nursaniyah, 2020). Pembiaran lansia tetap bekerja di masa pandemi menggambarkan kondisi perlindungan sosial bagi lansia yang belum menyeluruh. Interaksi pekerja lansia di luar rumah meningkatkan risiko mereka terpapar virus COVID-19. Meski demikian, pilihan untuk tetap bekerja di luar rumah merupakan pilihan yang cukup masuk akal dilakukan ketika keluarga, masyarakat, dan negara tidak dapat menjamin kecukupan hidup lansia di masa pandemi.

\section{Risiko Familisasi Lansia pada Masa Pandemi}

Lansia yang hidup dan bergantung pada keluarga berisiko mengalami kekerasan dari keluarga tersebut. Pelaku kekerasan bisa jadi adalah anggota keluarga yang tinggal di dalam satu rumah atau orang lain yang hidup berdekatan. Lansia dapat menerima kekerasan baik berupa fisik maupun verbal. Penganiayaan ini dapat digambarkan sebagai situasi ketika adanya tindakan yang dilakukan secara sengaja oleh orang yang merawat lansia tersebut atau orang lain yang menyebabkan timbulnya risiko terjadinya kekerasan (Mosqueda, et al., 2016). Kondisi kesehatan yang sudah tidak prima mengakibatkan lansia memiliki keterbatasan fisik dan kesulitan dalam melakukan perlawanan ketika mendapatkan kekerasan secara langsung.

Menurut data Susenas tahun 2019, tercatat 9,38\% lansia tinggal sendiri, 27,3\% tinggal bersama keluarga, dan 40,64\% tinggal bersama dengan tiga generasi (BPS, 2019). Dari data tersebut, tidak dapat disimpulkan bahwa lansia yang tinggal sendiri lebih tidak sejahtera dibanding lansia yang tinggal dengan orang lain karena lansia yang tinggal dengan orang lain berpotensi mendapatkan kekerasan secara langsung. Selain itu, lansia yang tinggal sendiri juga kemungkinan besar akan kesulitan mendapat bantuan secara cepat jika terjadi suatu hal darurat. Berkaitan dengan hal tersebut, pemerintah melakukan upaya untuk mencegah terjadinya kekerasan yang spesifik terhadap lansia, salah satunya melalui Kementerian Pemberdayaan Perempuan dan Perlindungan Anak dengan mengeluarkan Panduan Perlindungan Lanjut Usia Berperspektif Gender pada Masa COVID-19. Panduan tersebut diharapkan menjadi acuan bagi lintas kementerian, lembaga, dan organisasi pemerintah daerah yang berkaitan dengan urusan perempuan dalam penanganan tindak kekerasan berbasis gender bagi perempuan lansia (Kementerian Pemberdayaan Perempuan dan Perlindungan Anak RI, 2020d).

Lansia yang bergantung kepada keluarga berkemungkinan besar tidak tercukupi kebutuhan hidup sehari-harinya. Tidak seluruh lansia dirawat oleh keluarga yang berekonomi baik. Pada 2019, tercatat ada 12,6 juta lansia miskin dan rentan $(40 \%$ status sosial ekonomi terbawah), 10,7 juta lansia di dalam keluarga, dan 1,9 juta lansia di luar keluarga (Kementerian Sosial RI, 2020f). Selanjutnya, pada tahun 2019, jumlah lansia terbanyak menurut kelompok pengeluaran berada pada kelompok pengeluaran $40 \%$ terbawah yaitu sebanyak $43,84 \%$. Hanya $18,91 \%$ dari total lansia yang berada pada kelompok pengeluaran rumah tangga di 20\% teratas (BPS, 2019). Data tersebut menggambarkan lansia yang belum mapan secara finansial.

\section{Metode Penelitian}

Penelitian ini bertujuan untuk mengidentifikasi bantuan sosial yang didapatkan oleh lansia yang bersumber dari pemerintah daerah dan pusat pada masa pandemi. Kondisi tersebut dapat dipahami dengan mengkaitkan pada konsep defamilisasi dan familisasi. Konsep tersebut digunakan karena penggunaannya pada kajian lansia di Indonesia masih terbatas. Hal ini juga didukung oleh budaya dan kebiasaan penduduk di Indonesia yang mayoritas masih 
menggantungkan perawatan hidup lansia kepada keluarga. Kondisi lansia di masa pandemi pada satu sisi dapat ditolong karena adanya informal social security melalui familisasi, namun juga dapat menimbulkan risiko familisasi (keterbatasan ekonomi keluarga, mengalami kekerasan). Penelitian ini mendata jenis-jenis bantuan sosial yang bersumber dari pemerintah pusat dan daerah. Pemerintah pusat merujuk kepada Kementerian Sosial dan Kementerian Pemberdayaan Perempuan dan Perlindungan Anak. Data tentang bantuan sosial pada level daerah diperoleh dari Pemerintah DKI Jakarta dan Jawa Timur. Bantuan sosial tersebut nantinya meberikan gambaran praktik familisasi dan defamilisasi lansia pada masa pandemi dan risiko yang muncul bagi lansia baik dari familisasi maupun defamilisasi. Pemilihan Provinsi DKI Jakarta dan Jawa Timur adalah atas pertimbangan keduanya sebagai dua provinsi yang memiliki kasus tertinggi dari seluruh provinsi di Indonesia per tanggal 25 Agustus 2020 (Tabel 1).

\section{Metode Pengumpulan Data}

Sumber data penelitian ini didapatkan dari hasil desk review. Data bantuan sosial (nonkontribusi) yang diberikan kepada lansia pada masa pandemi diperoleh dari media daring, yaitu regulasi pusat dan web-based institutional report yang ada pada bulan Maret-Juli 2020 (khusus data bantuan sosial lansia dari Kementerian Sosial RI pada Mei-Juli 2020). Informasi terkait bantuan yang diberikan oleh Kementerian Pemberdayaan Perempuan dan Perlindungan Anak RI diperoleh dari laman resmi milik kementerian pada bagian siaran pers. Data bantuan dari Kementerian Sosial RI didapatkan dari laman resmi milik kementerian pada bagian berita terkini oleh Humas Ditjen Rehabilitasi Sosial. Data bantuan sosial dari Pemerintah DKI Jakarta didapatkan dari laman Jakarta Tanggap
COVID-19. Terakhir, data bantuan sosial dari Pemerintah Jawa Timur didapatkan dari media daring. Tulisan ini mengkaji beberapa peraturan terkait dengan regulasi pusat yang berhubungan dengan bantuan sosial kepada lansia.

Lansia dipilih sebagai fokus dari penerima bantuan sosial karena, pada masa pandemi, lansia menghadapi beberapa tantangan, seperti keterbatasan untuk memasuki dunia kerja, kehilangan atau berkurangnya dana pensiun, gangguan aktivitas sehari-hari karena ada pembatasan kegiatan di luar rumah, gangguan emosional (pelaksanaan isolasi diri), dan kerentanan terhadap penularan virus COVID-19 (Morrow-Howell, Galucia, \& Swinford, 2020). Penulis juga melakukan pengayaan informasi terkait dengan familisasi dan defamilisasi yang berkaitan erat dari adanya perlindungan sosial yang diberikan oleh negara, baik berupa bantuan sosial maupun jaminan sosial. Risiko dari familisasi dan defamilisasi ini juga dapat meningkat pada masa pandemi. Informasi tersebut diperoleh dari beberapa sumber, yaitu jurnal dan policy brief. Bantuan yang dibahas dalam penelitian ini adalah bantuan sosial yang diberikan oleh pemerintah. Penelitian ini menyertakan pencatatan waktu penarikan data yang dilakukan pada seluruh literatur yang digunakan (Ferrari, 2015).

Penelitian ini menggunakan data pendukung terkait statistik lansia di Indonesia yang bersumber dari laporan oleh Badan Pusat Statistik (BPS) pada tahun 2010 hingga 2019. Data tersebut digunakan sebagai bahan penyajian data time series untuk angka kesakitan lansia tahun 2011-2019, rasio ketergantungan lansia tahun 2010-2019, dan rumah tangga lansia yang memiliki jaminan kesehatan tahun 2012-2019.

\section{Teknik Analisis Data}

Pada literature review, analisis data tetap dilakukan, tidak hanya pengumpulan data dari

Tabel 1

Data Kasus COVID-19 di Lima Provinsi Tertinggi per 25 Agustus 2020

\begin{tabular}{ccccc}
\hline No & Provinsi & $\begin{array}{c}\text { Jumlah Kasus Lansia } \\
(\mathbf{2 6 0} \text { tahun) }\end{array}$ & $\begin{array}{c}\text { Total Jumlah } \\
\text { Kasus }\end{array}$ & $\begin{array}{c}\text { Lansia yang Terpapar } \\
\text { COVID-19 (\%) }\end{array}$ \\
\hline 1 & DKI Jakarta & 3.824 & 33.470 & 11,47 \\
2 & Jawa Timur & 4.328 & 30.315 & 14,26 \\
3 & Jawa Tengah & 1.589 & 12.476 & 12,69 \\
4 & Sulawesi Selatan & 914 & 11.470 & 7,99 \\
5 & Jawa Barat & 680 & 9.283 & 7,37 \\
\hline
\end{tabular}

Sumber: (Gugus Tugas Percepatan Penanganan COVID-19, 2020b) 
bacaan-bacaan yang berkaitan dengan topik pembahasan (T.Gregory \& Denniss, 2018). Data yang dikelompokkan diperoleh dari media daring, baik berupa jurnal maupun buku. Informasi bantuan sosial yang didapatkan dari media daring dikelompokkan dengan spesifik pada bantuan yang menyebutkan lansia sebagai salah satu penerima manfaat. Setelah pengumpulan sumber tersebut, dilakukan pengelompokan literatur yang berdasarkan pada informasi terkait defamilisasi dan risikonya, familisasi dan risikonya, kebijakan sosial untuk lansia, dan bantuan sosial untuk lansia di masa pandemi. Setelah kategorisasi literatur, dilakukan penyajian data. Data tersebut dianalisis, direduksi, disajikan, dan ditarik kesimpulannya (Miles, Huberman, \& Saldana, 2014). Reduksi data dilakukan karena terdapat literatur yang tidak menyebutkan secara spesifik sasaran penerima manfaat bantuan sosial dari pemerintah dengan kategori lansia. Kesimpulan ditarik dari desk review, bukan untuk melakukan generalisasi, melainkan untuk melihat peluang yang dapat dilakukan pemerintah selanjutnya untuk mengatasi tantangan jumlah penduduk lansia di Indonesia.

\section{Hasil}

Mayoritas program bantuan yang diberikan kepada lansia pada masa pandemi adalah bantuan yang sifatnya tidak rutin, hanya diberikan dalam satu waktu. Sebagai contoh, dalam hal pembagian paket sembako, belum ditemukan bantuan sosial yang diberikan secara rutin selama masa pandemi. Lansia penerima manfaat pada masa pandemi dalam kurun waktu Maret-Juli 2020 menerima paket sembako yang diberikan sebanyak satu kali dari Kementerian Sosial, Kementerian Pemberdayaan Perempuan dan Perlindungan Anak, Pemerintah DKI Jakarta, dan Pemerintah Jawa Timur.

Ada upaya pemerataan distribusi bantuan (informasi di tabel 2 nomor 10) oleh Kementerian Sosial RI, yaitu dengan cara memberikan bantuan kepada lansia yang belum mendapatkan bantuan sosial lain berupa Program Keluarga Harapan (PKH), Bantuan Pangan Non Tunai (BNPT), Bantuan Sosial Tunai (BST), dan Bansos Reguler Program Rehabilitasi Sosial. Hal tersebut penting untuk dilakukan sebagai langkah untuk menghindari pengulangan pemberian bantuan terhadap penerima manfaat yang sama sehingga lansia lain tidak mendapatkan bagiannya.
Di samping itu, lansia mengalami cobaan berlapis; selain harus tetap berjuang di masa pandemi, ada beberapa lansia yang kondisinya bertambah rentan karena harus menghadapi bencana. Salah satunya adalah bencana banjir yang menimpa beberapa kelurahan di Kecamatan Bantaeng dan Kecamatan Bissappu (informasi di tabel 2 nomer 10). Lansia menghadapi risiko jatuh dan cedera saat banjir, kondisi tubuh yang terpengaruh dari bencana banjir --daya tahan tubuh menurun--- dapat membuat lansia semakin rentan terkena virus COVID-19. Bencana lain yang terjadi pada masa pandemi adalah angin puting beliung. Akibat dari bencana tersebut adalah lansia mengalami cedera di kaki karena tertimpa runtuhan rumah (informasi di tabel 2 nomer 9).

Pemerintah DKI Jakarta menyediakan poster himbauan untuk menjaga lansia agar terhindar dari COVID-19. Melalui poster digital tersebut Pemerintah DKI Jakarta menunjukkan adanya kepedulian khusus kepada lansia sebagai salah satu kelompok rentan (Pemerintah DKI Jakarta, 2020c). Selain itu, Kementerian Pemberdayaan Perempuan dan Perlindungan Anak menggalakkan kembali Gerakan Sayangi Lansia (GSL) yang bertujuan agar lansia mendapatkan akses edukasi dan pendampingan untuk menyesuaikan diri dengan perubahan new normal (Kementerian Pemberdayaan Perempuan dan Perlindungan Anak RI, 2020c). Di samping itu, Balai Rehabilitasi Lansia berupaya untuk menampung lansia terlantar terdampak COVID-19, yaitu lansia yang terjaring razia gelandangan dan pengemis. Pelayanan lansia terlantar ini melingkupi pemenuhan kebutuhan dasar, pendampingan, dan intervensi rehabilitasi sosial lanjut sesuai kebutuhan, termasuk penelusuran keberadaan keluarga (Kementerian Sosial RI, 2020k).

\section{Diskusi}

Defamilisasi adalah upaya untuk menciptakan lansia yang independen. Tanpa adanya intervensi dari keluarga, lansia tetap bisa memenuhi kebutuhan hidup sehari-hari. Namun, defamilisasi ini tidak dapat dipisahkan dari bantuan yang diberikan oleh pemerintah, khususnya pada masa pandemi. Pada realitanya, perlindungan sosial berbasis negara, baik dalam bentuk jaminan sosial maupun bantuan sosial masih butuh beberapa perbaikan guna kemerataan akses dan distribusi. Bantuan sosial 
Tabel 2

Daftar Bantuan Sosial untuk Lansia di Masa Pandemi

\begin{tabular}{|c|c|c|c|c|}
\hline No. & Nama Program & Lembaga & Sasaran & Keterangan \\
\hline 1. & $\begin{array}{l}\text { Bantuan Sosial } \\
\text { dalam Periode } \\
\text { Penerapan } \\
\text { Pembatasan } \\
\text { Sosial Berskala } \\
\text { Besar COVID-19 } \\
\text { (Penyaluran bansos } \\
\text { 9-23 April 2020) }\end{array}$ & $\begin{array}{l}\text { Pemerintah } \\
\text { Provinsi DKI } \\
\text { Jakarta }\end{array}$ & $\begin{array}{l}\text { Keluarga miskin dan } \\
\text { rentan (termasuk } \\
\text { penerima Kartu } \\
\text { Lansia Jakarta) yang } \\
\text { bermukim di Jakarta }\end{array}$ & $\begin{array}{l}\text { Bantuan sosial senilai Rp } 149.500 \text { per paket } \\
\text { (Pemerintah DKI Jakarta, } 2020 \mathrm{~d} \text { ) berupa } \\
\text { komoditas bahan pangan pokok (beras, bahan } \\
\text { makanan berprotein, biskuit dan minyak } \\
\text { goreng), masker kain dan sabun mandi } \\
\text { batang. (Pemerintah DKI Jakarta, } 2020 \text { b) } \\
\text { Sumber dana: APBD DKI Jakarta dan } \\
\text { Kementerian Sosial RI }\end{array}$ \\
\hline 2. & $\begin{array}{l}\text { Bantuan Sosial } \\
\text { COVID-19 Tahap } 2 \\
\text { (Penyaluran bansos } \\
\text { 14-22 Mei 2020) }\end{array}$ & $\begin{array}{l}\text { Pemerintah } \\
\text { Provinsi DKI } \\
\text { Jakarta }\end{array}$ & $\begin{array}{l}\text { Keluarga miskin dan } \\
\text { rentan (termasuk } \\
\text { penerima Kartu } \\
\text { Lansia Jakarta) yang } \\
\text { bermukim di Jakarta. }\end{array}$ & $\begin{array}{l}\text { Bantuan Sosial senilai Rp } 275.000 \text { per paket. } \\
\text { Komoditas bahan pangan pokok (beras, } \\
\text { sarden, biskuit, minyak goreng, kecap, tepung } \\
\text { terigu dan bihun) dan sabun mandi batang. } \\
\text { (Pemerintah DKI Jakarta, } 2020 \text { a) } \\
\text { Sumber dana: APBD DKI Jakarta dan } \\
\text { Kementerian Sosial RI }\end{array}$ \\
\hline 3. & Kartu Lansia Jakarta & $\begin{array}{l}\text { Pemerintah } \\
\text { Provinsi DKI } \\
\text { Jakarta }\end{array}$ & Lansia & $\begin{array}{l}\text { Target tahun } 2020 \text { untuk } 77.524 \text { lansia. Dana } \\
\text { sebesar Rp } 600.000 \text { per bulan. (Ramadhan, } \\
\text { 2020) }\end{array}$ \\
\hline 4. & $\begin{array}{l}\text { Bantuan Paket } \\
\text { Sembako }\end{array}$ & $\begin{array}{l}\text { Pemerintah } \\
\text { Provinsi Jawa } \\
\text { Timur }\end{array}$ & Lansia & $\begin{array}{l}\text { Bantuan Sembako (beras, mi instan, biskuit } \\
\text { dan paket minuman untuk kesehatan) } \\
\text { sebanyak } 2300 \text { paket. Dengan rincian } 2000 \\
\text { paket berasal dari Kementerian Sosial } \\
\text { Republik Indonesia dan } 300 \text { paket dari } \\
\text { Pemerintah Provinsi Jawa Timur. } \\
\text { (Zahro, 2020) }\end{array}$ \\
\hline 5. & $\begin{array}{l}\text { Bantuan Sosial } \\
\text { Sembako }\end{array}$ & $\begin{array}{l}\text { Kementerian } \\
\text { Sosial RI }\end{array}$ & $\begin{array}{l}\text { Lansia sebanyak } \\
6.486 \text { orang. }\end{array}$ & $\begin{array}{l}\text { Bantuan tersebut akan didistribusikan ke } \\
\text { lima provinsi, yaitu Banten, Jawa Barat, Jawa } \\
\text { Tengah, Jawa Timur dan Daerah Istimewa } \\
\text { Yogyakarta. (Kementerian Sosial RI, 2020i) }\end{array}$ \\
\hline 6. & $\begin{array}{l}\text { Bantuan Sosial } \\
\text { Sembako }\end{array}$ & $\begin{array}{l}\text { Kementerian } \\
\text { Sosial RI }\end{array}$ & $\begin{array}{l}\text { Lansia sebanyak } \\
4.673 \text { orang }\end{array}$ & $\begin{array}{l}\text { Bantuan didistribusikan bagi lansia se- } \\
\text { Jabodetabek. Paket sembako senilai Rp } \\
\text { 300.000. (Zulfikar, 2020) }\end{array}$ \\
\hline 7. & Dapur Umum & $\begin{array}{l}\text { Kementerian } \\
\text { Sosial RI }\end{array}$ & $\begin{array}{l}107 \text { lansia di } \\
\text { Kecamatan Bantaeng } \\
\text { dan } 407 \text { lansia di } \\
\text { Kecamatan Bissappu, } \\
\text { Kabupaten Bantaeng, } \\
\text { Sulawesi Selatan. }\end{array}$ & $\begin{array}{l}\text { Pendirian dapur umum di tempat } \\
\text { pengungsian. (Kementerian Sosial RI, 2020c) }\end{array}$ \\
\hline 8. & Paket Sembako & $\begin{array}{l}\text { Kementerian } \\
\text { Sosial RI }\end{array}$ & $\begin{array}{l}128 \text { orang (lansia } \\
\text { dan penyandang } \\
\text { disabilitas mental) di } \\
\text { Kota Surakarta }\end{array}$ & $\begin{array}{l}\text { Bantuan sembako senilai Rp. } 300.000- \\
\text { per paket (beras premium, mi instas, jus } \\
\text { kemasan, biskuit). (Kementerian Sosial RI, } \\
2020 \mathrm{~g} \text { ) }\end{array}$ \\
\hline 9. & Paket Sembako & $\begin{array}{l}\text { Kementerian } \\
\text { Sosial RI }\end{array}$ & 3038 lansia & $\begin{array}{l}\text { Refocusing anggaran dan merealokasikan } \\
\text { anggarannya untuk penambahan bantuan } \\
\text { sosial berupa sembako di } 3 \text { provinsi } \\
\text { yaitu Jawa Barat, Banten dan Lampung. } \\
\text { (Kementerian Sosial RI, 2020d) } \\
100 \text { lansia di Kabupaten Tulang Bawang, } \\
\text { korban bencana angin puting beliung. } \\
\text { (Kementerian Sosial RI, 2020b) }\end{array}$ \\
\hline 10. & Paket Sembako & $\begin{array}{l}\text { Kementerian } \\
\text { Sosial }\end{array}$ & 600 lansia & $\begin{array}{l}\text { Paket sembako senilai Rp } 300.000 \text { (beras, } \\
\text { susu khusus lansia, minyak goreng, mie } \\
\text { instan, sarden, minuman penambah daya } \\
\text { tahan tubuh, sabun mandi dan sabun cuci). } \\
\text { (Kementerian Sosial RI, } 2020 \text { ) } \\
\text { Refocussing anggaran dan dibagikan di } \\
\text { wilayah Provinsi Sulawesi Selatan dan } \\
\text { Sulawesi Barat } \\
\text { (Kementerian Sosial RI, 2020l) }\end{array}$ \\
\hline
\end{tabular}




\section{Lanjutan Tabel 2}

\begin{tabular}{|c|c|c|c|c|}
\hline 11. & $\begin{array}{l}\text { Paket Pemenuhan } \\
\text { Kebutuhan Spesifik }\end{array}$ & $\begin{array}{l}\text { Kementerian } \\
\text { Pemberdayaan } \\
\text { Perempuan dan } \\
\text { Perlindungan } \\
\text { Anak RI }\end{array}$ & $\begin{array}{l}\text { Keluarga dengan } \\
\text { lansia sebanyak } 73 \\
\text { paket. }\end{array}$ & $\begin{array}{l}\text { Barang-barang kebutuhan spesifik yaitu } \\
\text { popok lansia, susu lansia. (Kementerian } \\
\text { Pemberdayaan Perempuan dan Perlindungan } \\
\text { Anak RI, 2020a) } \\
\text { Sumber dana: Bantuan dari Perusahaan, } \\
\text { Organisasi Wanita, Donatur }\end{array}$ \\
\hline 13. & $\begin{array}{l}\text { Paket Pemenuhan } \\
\text { Kebutuhan Spesifik }\end{array}$ & $\begin{array}{l}\text { Kementerian } \\
\text { Pemberdayaan } \\
\text { Perempuan dan } \\
\text { Perlindungan } \\
\text { Anak RI }\end{array}$ & $\begin{array}{l}468 \text { lansia di DKI } \\
\text { Jakarta }\end{array}$ & $\begin{array}{l}\text { Bantuan bagi perempuan lansia berupa } \\
\text { sabun, masker, supplement, sarung tangan, } \\
\text { susu dan diapers untuk perempuan lansia } \\
\text { dan disabilitas. (Kementerian Pemberdayaan } \\
\text { Perempuan dan Perlindungan Anak RI, } \\
\text { 2020b) }\end{array}$ \\
\hline
\end{tabular}

Sumber: Olahan Data Penulis, 2020

yang diberikan oleh pemerintah kepada lansia dapat meminimalkan beban keluarga untuk menanggung lansia.

Pada masa pandemi, lansia potensial (merujuk pada kategori lansia pada UU nomor 13 tahun 1998 tentang Kesejahteraan Lanjut Usia) memiliki hambatan dalam menghasilkan produk dan atau jasa. Selain itu, himbauan untuk menghindari kegiatan di luar rumah membuka peluang bagi lansia potensial untuk kehilangan pekerjaan. Kondisi ini dapat semakin memprihatinkan ketika lansia potensial yang berhenti bekerja tidak memiliki dana pensiun atau tabungan lainnya. Risiko defamilisasi akan semakin besar pada masa pandemi sehingga dapat berpengaruh terhadap lansia potensial. Kondisi pandemi saat ini sangat memungkinkan bergesernya lansia yang sebelumnya sudah melakukan defamilisasi (atau mengarah ke defamilisasi) kembali ke familisasi. Bantuan sosial yang diberikan oleh pemerintah membantu lansia dalam melakukan defamilisasi, meski tidak seutuhnya. Pada konteks di Indonesia, familisasi masih dominan karena didukung oleh bantuan dari komunitas. Negara masih memiliki keterbatasan anggaran untuk memberikan bantuan berkelanjutan yang dapat diakses oleh seluruh lansia.

Kondisi serupa juga dapat menimpa lansia tidak potensial. Pada masa sebelum pandemi, mereka telah menggantungkan hidup dari bantuan (keluarga, pemerintah dan atau komunitas). Keluarga yang menanggung lansia tidak potensial tidak dijamin akan tetap memiliki pekerjaan di masa pandemi. Jika anggota keluarga tersebut mengalami pemutusan hubungan kerja (PHK) atau menurunnya pendapatan, dukungan dana bagi kebutuhan lansia tidak potensial akan berkurang (risiko familisasi). Keluarga masih menjadi pilihan utama bagi para lansia untuk menggantungkan hidup (familisasi). Lansia juga berpotensi untuk dapat membantu keluarga, misalnya menjaga cucu ketika anak mereka bekerja. Pemerintah juga telah membuat program bantuan bagi lansia pada masa sebelum pandemi, yaitu Bantuan Pangan Non Tunai (BPNT), Program Keluarga Harapan (PKH), Program Asistensi Sosial Lanjut Usia Terlantar (ASLUT), dan Program Rehabilitasi Sosial Lanjut Usia (PROGRESS LU). Program-program tersebut diharapkan agar meningkatkan jumlah lansia penerima manfaat. Diperlukan kesempatan yang sama bagi seluruh lansia yang membutuhkan dalam mengakses perlindungan sosial yang diberikan oleh pemerintah.

\section{Kesimpulan}

Terdapat tantangan bagi pemerintah untuk terus melakukan pemutakhiran data. Hal ini dilakukan guna memastikan seluruh bantuan sosial bagi para lansia terdistribusi dengan baik. 
Selain itu, bantuan sosial ini juga diharapkan dapat dilakukan secara reguler. Bantuan sosial pada masa pandemi bukan berarti untuk melakukan pengentasan kemiskinan, melainkan sebagai jaring pengaman sosial bagi lansia untuk tetap bertahan di masa pandemi. Bantuan sosial ini juga dapat mengurangi ketergantungan lansia terhadap keluarga atau defamilisasi.

Pemerintah juga harus menyiapkan skema bantuan sosial kepada lansia pada pascamasa pandemi. Hal ini dilakukan untuk memastikan seluruh lansia, terutama lansia yang berada pada golongan miskin, mendapatkan kesempatan pemenuhan kebutuhan hidup sehari-hari. Kondisi lain menunjukkan tidak sedikit lansia yang harus diam di rumah karena tidak lagi dapat bekerja pada masa pandemi. Oleh sebab itu, dibutuhkan dukungan dari negara untuk mengatasi risiko defamilisasi sambal para lansia tersebut mendapat dukungan kembali dari keluarga dan komunitas.

Penuaan populasi dapat berdampak pada kinerja perekonomian, berupa tingginya rasio ketergantungan lansia kepada penduduk usia produktif. Berkaitan dengan hal tersebut, dibutuhkan persiapan berupa jaminan sosial seperti jaminan kesehatan dan pelayanan kesehatan jangka panjang (long term care) yang dapat diakses oleh seluruh lansia serta skema pensiun bagi pekerja, baik sektor formal maupun informal untuk meminimalkan risikodari populasi yang menua. Jaminan terhadap ketersediaan dana pensiun dan panti tempat merawat lansia dapat mengurangi risiko defamilisasi karena tersedia jaminan bagi lansia untuk memenuhi kebutuhan hidup tanpa bergantung pada pemberian dari keluarga.

\section{Referensi}

BPS. (2010). Statistik Penduduk Lanjut Usia 2010. Jakarta: Badan Pusat Statistik. Retrieved Agustus 20, 2020, from https:// www.bps.go.id/publication/download. html?nrbvfeve=0TA3ZDg5Y2Y5MmZm MGFjMTY3M2Q2OWNi\&Xzmn=aHR0 cHM6Ly93d3cuYnBzLmdvLmlkL3B1Ym xpY2F0aW9uLzIwMTIvMDMvMzAvOTA 3ZDg5Y2Y5MmZmMGFjMTY3M2Q2OW NiL3N0YXRpc3Rpay1wZW5kdWR1ay1 sYW5qdXQtdXNpYS0yMDEwLmh0bWw \%3D\&twoadfnoa.

BPS. (2011). Statistik Penduduk Lanjut Usia 2011. Jakarta: Badan Pusat Statistik.
Retrieved Agustus 20, 2020, from https:// www.bps.go.id/publication/download. html?nrbvfeve=ODQ3YzkzZTkxMW M5ODFmYWJjNWMwYjU 5\&xzm n=a HR0cHM6Ly93d3cuYnBzLmdvLmlkL3B 1YmxpY2F0aW9uLzIwMTIvMTEvMDcv ODQ3YzkzZTkxMWM5ODFmYWJjNWM wYjU5L3N0YXRpc3Rpay1wZW5kdWR1 ay1sYW5 qdXQtdXNpYS1pbmRvbmVza WEtMjAxMS5odG1s.

BPS. (2012). Statistik Penduduk Lanjut Usia 2012. Jakarta: Badan Pusat Statistik. Retrieved Agustus 20, 2020, from https:// www.bps.go.id/publication/download. h tml? nrbvfeve=0 D J h OGY 0 M Tky M jBIYjYzOGQ5ZGJiMjk3 \&xzmn =aHR 0cHM6Ly93d3cuYnBzLmdvLmlkL3B1Y mxpY2F0aW9uLzIwMTMvMDkvMjUvO DJhOGY0MTkyMjBIYjYzOGQ5ZGJiMjk3L 3N0YXRpc3Rpay1wZW5kdWR1ay1sYW 5qdXQtdXNpYS0yMDEyLmh0bWw\%3D \&twoadfnoa.

BPS. (2013). Statistik Penduduk Lanjut Usia 2013. Jakarta: Badan Pusat Statistik. Retrieved Agustus 20, 2020, from https:// www.bps.go.id/publication/download. html?nrbvfeve=ZmQ2ZjBhMjVhMD c5ZjhiMDBhOGYwN mEy \& xz mn =aH R0cHM6Ly93d3cuYnBzLmdvLmlkL3B1 YmxpY2F0aW9uLzIwMTQvMTAvMjkvZ mQ2ZjBhMjVhMDc5ZjhiMDBhOGYwNm EyL3N0YXRpc3Rpay1wZW5kdWR1ay1s YW5qdXQtdXNpYS0yMDEzLmh0bWw\% 3D\&twoadfnoa.

BPS. (2014). Statistik Penduduk Lanjut Usia 2014. Jakarta: Badan Pusat Statistik. Retrieved Agustus 20, 2020, from https://www. bappenas.go.id/files/data/Sumber_Daya Manusia_dan_Kebudayaan/Statistik\%20 Penduduk\% 20 Lanjut $\% 20$ Usia $\% 20$ Indonesia\%202014.pdf.

BPS. (2015). Statistik Penduduk Lanjut Usia 2015. Jakarta: Badan Pusat Statistik. Retrieved Agustus 20, 2020, from https:// www.bps.go.id/publication/download. html?nrbvfeve=ZjlkMDBhZDcyMjg $1 \mathrm{Mzk} 2 \mathrm{ZWNiMTgwMWRj \& xzmn=aHR}$ 0cHM6Ly93d3cuYnBzLmdvLmlkL3B1Y mxpY2F0aW9uLzIwMTYvMTEvMDcvZjl kMDBhZDcyMjg1Mzk2ZWNiMTgwMWR jL3N0YXRpc3Rpay1wZW5kdWR1ay1s YW5qdXQtdXNpYS0yMDE1Lmh0bWw\% 3D\&twoadfnoa. 
BPS. (2016). Statistik Penduduk Lanjut Usia 2016. Jakarta: Badan Pusat Statistik. Retrieved Agustus 20, 2020, from https:// www.bps.go.id/publication/download. html? n rbvfeve = M TA 3 N z y y W E yMGYzZjhjYjA 4ZDlkYWJl\&xzmn= aHR0cHM6Ly93d3cuYnBzLmdvLmlkL3B 1YmxpY2F0aW9uLzIwMTcvMTEvMTcv MTA3NzUyYWEyMGYzZjhjYjA4ZDlkYWJl L3N0YXRpc3Rpay1wZW5kdWR1ay1sYW 5qdXQtdXNpYS0yMDE2Lmh0bWw\%3D\& twoadfnoa.

BPS. (2017). Statistik Penduduk Lanjut Usia 2017. Jakarta: Badan Pusat Statistik. Retrieved Agustus 20, 2020 , from https://www.bps.go.id/publication/ download.html?nrbvfeve=N2ExMzBhMjJh Y T I 5 Y 2 M 4 M jE 5 Yz V k M T U z \& X z m n $=$ aHR0cHM6Ly93d 3cuYnBzLmdvLmlkL3 B1YmxpY2F0aW9uLzIwMTgvMDQvMT MvN2ExMzBhMjJhYTI5Y2M4MjE5YzVk MTUzL3N0YXRpc3Rpay1wZW5kdWR1 ay1sYW5qdXQtdXNpYS0yMDE3Lmh0bW w\%3D\&twoadfnoa.

BPS. (2018). Statistik Penduduk Lanjut Usia 2018. Jakarta: Badan Pusat Statistik. Retrieved Agustus 20, 2020, from https:// www.bps.go.id/publication/download. html? nrbvfeve=ZWFkYm FiNjUw N 2 M w N j I 5 N G I 3 N G F k Z j c x \& x z m n $=$ aHR0cHM6Ly93d 3cuYnBzLmdvLmlkL3 B1YmxpY2F0aW9uLzIwMTgvMTIvMjEv ZWFkYmFiNjUwN2MwNjI5NGI3NGFkZj cXL3N0YXRpc3Rpay1wZW5kdWR1ay1s YW5qdXQtdXNpYS0yMDE4Lmh0bWw\% 3D\&twoadfnoa.

BPS. (2019). Statistik Penduduk Lanjut Usia 2019. Jakarta: Badan Pusat Statistik. Retrieved Agustus 20, 2020, from https:// www.bps.go.id/publication/2019/12/20/ ab17e75dbe630e05110ae53b/statistikpenduduk-lanjut-usia-2019.html.

Chau, R. C., \& Yu, S. W. (2019). Familization risks, defamilization risks and older women. Journal of Women \& Aging, 1-16.

Ferrari, R. (2015). Writing narrative style literature reviews. Medical Writing, 230-235. Retrieved Agustus 28, 2020.

Gugus Tugas Percepatan Penanganan COVID-19. (2020a). Peta Sebaran. Retrieved Agustus 26, 2020, from Gugus Tugas Percepatan Penanganan COVID-19: https://covid19. go.id/peta-sebaran.
Gugus Tugas Percepatan Penanganan COVID-19. (2020b). Peta Sebaran Kasus Per Provinsi. Retrieved Agustus 25, 2020, from Gugus Tugas Percepatan Penanganan COVID-19: https://covid19.go.id/peta-sebaran.

Hastuti, Y., Darwin, M., Sukamdi, \& Hadna, A. H. (2018). Perawatan Lansia: Menerjemahkan Peraturan Nasional ke dalam Program Lokal di Kota Yogyakarta. Populasi, 29-46.

Israle, S., \& Spannagel, D. (2018). Material deprivation in the EU:A multi-level analysis on the influence of decommodification and defamilisation policies. Acta Sociologica, 1-22.

Johnson, R. W., \& Butrica, B. A. (2012, May 3). Age Disparitiesin Unemploymentand Reemployment during the Great Recession and Recovery. Retrieved Agustus 20, 2020, from Urban Institute: https://www.urban.org/sites/ default/files/publication/25431/412574age-disparities-in-unemployment-andreemployment-during-the-great-recessionand-recovery.pdf.

Kementerian Koordinator Bidang Pembangunan Manusia dan Kebudayaan RI. (2015). Analisis Kebijakan Pemberdayaan dan Perlindungan Sosial Lanjut Usia. Jakarta: Deputi Bidang Koordinasi Penanggulangan Kemiskinan dan Perlindungan Sosial.

Kementerian Pemberdayaan Perempuan dan Perlindungan Anak RI. (2020a, Mei 17). Berkontribusi Penuhi Kebutuhan Spesifik Perempuan dan Anak, Kemen PPPA Apresiasi Dunia Usaha dan Para Donatur. Retrieved Agustus 25, 2020, from Kementerian Pemberdayaan Perempuan dan Perlindungan Anak RI: https:// www.kemenpppa.go.id/index.php/page/ $\mathrm{read} / 29 / 2674 /$ berkontribusi-penuhikebutuhan-spesifik-perempuan-dan-anakkemen-pppa-apresiasi-dunia-usaha-danpara-donatur.

Kementerian Pemberdayaan Perempuan dan Perlindungan Anak RI. (2020b, Mei 8). Implementasi Gerakan \#Berjarak, Kemen PPPA Bagi Paket Kebutuhan Spesifik Perempuan dan Anak. Retrieved Agustus 20, 2020, from Kementerian Pemberdayaan Perempuan dan Perlindungan Anak RI: https://www.kemenpppa.go.id/index. $\mathrm{php} / \mathrm{page} / \mathrm{read} / 29 / 2658 /$ implementasigerakan-berjarak-kemen-pppa-bagi-paketkebutuhan-spesifik-perempuan-dan-anak. 
Kementerian Pemberdayaan Perempuan dan Perlindungan Anak RI. (2020c, Juni 22). Menteri PPPA: Berdayakan Lansia di Era New Normal melalui Gerakan Sayang Lansia. Retrieved Agustus 25, 2020, from Kementerian Pemberdayaan Perempuan dan Perlindungan Anak RI: https:// www.kemenpppa.go.id/index.php/page/ $\mathrm{read} / 29 / 2737 /$ menteri-pppa-berdayakanlansia-di-era-new-normal-melalui-gerakansayang-lansia.

Kementerian Pemberdayaan Perempuan dan Perlindungan Anak RI. (2020d, Mei 13). Panduan Perlindungan Lansia Pada Masa COVID-19. Retrieved Agustus 10, 2020, from Bersama Jaga Keluarga Kita (BERJARAK) Kementerian Pemberdayaan Perempuan dan Perlindungan Anak RI: https://berjarak. kemenpppa.go.id/panduan-perlindunganlansia-pada-masa-COVID-19/.

Kementerian Sosial RI. (2020b, Juni 12). Balai "Budhi Dharma" Salurkan Bansos Sembako untuk Lansia dan Korban Puting Beliung. Retrieved Agustus 22, 2020, from Kementerian Sosial Republik Indonesia: https://kemsos.go.id/balai-budhi-dharmasalurkan-bansos-sembako-untuk-lansiadan-korban-puting-beliung.

Kementerian Sosial RI. (2020c, Juni 17). Balai "Gau Mabaji" Tangani Lansia Korban Banjir di Kabupaten Bantaeng. Retrieved Agustus 22, 2020, from Kementerian Sosial Republik Indonesia: https://kemsos.go.id/balai-gaumabaji-tangani-lansia-korban-banjir-dikabupaten-bantaeng.

Kementerian Sosial RI. (2020d, Juni 7). Bansos bagi Lansia TerdampakCOVID-19 Tersalurkan di Cianjur dan Sukabumi. Retrieved from Kementerian Sosial Republik Indonesia: https://kemsos.go.id/bansos-bagi-lansiaterdampak-COVID-19-tersalurkan-dicianjur-dan-sukabumi.

Kementerian Sosial RI. (2020e, Mei 8). Bukti Kemensos Hadir, 8.900 Lansia di 10 Provinsi Dapat Bansos. Retrieved Agustus 22, 2020, from Kementerian Sosial Republik Indonesia: https://kemsos.go.id/bukti-kemensoshadir-8900-lansia-di-10-provinsi-dapatbansos.

Kementerian Sosial RI. (2020f, Juli 15). Kebijakan Kemensos untuk Kesejahteraan Sosial Lansia. Retrieved Agustus 20, 2020, from Kementerian Sosial Republik Indonesia: https://kemsos.go.id/kebijakan-kemensosuntuk-kesejahteraan-sosial-lansia.

Kementerian Sosial RI. (2020g, Juni 28). Kementerian Sosial Salurkan Bantuan Sembako bagi 128 Warga Griya PMI Solo. Retrieved Agustus 22, 2020, from Kementerian Sosial RI: https://kemsos. go.id/kementerian-sosial-salurkanbantuan-sembako-bagi-128-warga-griyapmi.

Kementerian Sosial RI. (2020i, Juni 15). Resmi Diluncurkan, 6.486 Lansia di 5 Provinsi Siap Terima Bansos. Retrieved Agustus 25, 2020, from Kementerian Sosial Republik Indonesia: https://www.kemsos.go.id/ resmi-diluncurkan-6486-lansia-di-5provinsi-siap-terima-bansos.

Kementerian Sosial RI. (2020j, Juni 11). Sebrangi Laut, Balai Lansia "Gau Mabaji" Salurkan Paket Bansos. Retrieved from Kementerian Sosial Republik Indonesia: https://kemsos. go.id/sebrangi-laut-balai-lansia-gau-mabajisalurkan-paket-bansos.

Kementerian Sosial RI. (2020k, Mei 19). Tanggap COVID-19, Balai Lansia "Budhi Dharma" Tampung Lanjut Usia. Retrieved Agustus 22, 2020, from Kementerian Sosial Republik Indonesia: https://kemsos.go.id/tanggapCOVID-19-balai-lansia-budhi-dharmatampung-lanjut-usia.

Kementerian Sosial RI. (2020l, Juni 4). Tatanan Normal Baru, Balai Lansia "Gau Mabaji" Bagikan 600 Paket Bansos. Retrieved 22 Agustus, 2020, from Kementerian Sosial Republik Indonesia: https://kemsos.go.id/ tatanan-normal-baru-balai-lansia-gaumabaji-bagikan-600-paket-bansos.

Kementerian Sosial RI. (2020m, Juni 5). Terima Bantuan PKH, KPM Harus Penuhi Kewajiban. Retrieved Agustus 20, 2020, from Kementerian Sosial Republik Indonesia: https://www.kemsos.go.id/terima-bantuanpkh-kpm-harus-penuhi-kewajiban.

Lindawati. (2019, Oktober 10). Lokakarya Memperingati Hari Lansia International. Retrieved Agustus 17, 2020, from Asosiasi Alumni Program Beasiswa Amerika Indonesia: https://alpha-i.or.id/kabaralpha-i/event/lokakarya-memperingatihari-lansia-international/.

Lohmann, H., \& Zagel, H. (2016). Family policy in comparative perspective: The concepts and measurement of familization and 
defamilization. Journal of European Social Policy, 48-65.

Marchiondo, L. A., Gonzales, E., \& Williams, L. J. (2019). Trajectories of Perceived Workplace Age Discrimination and Long-Term Associations with Mental, Self-Rated, and Occupational Health. Journals of Gerontology: Social Sciences, 655-663. Retrieved Agustus 21, 2020.

Miles, M. B., Huberman, A. M., \& Saldana, J. (2014). Qualitative Data Analysis: A Methods Sourcebook. Third Edition. California: SAGE Publications, Inc.

Minchung, H., \& Tomoaki, Y. (2017, March). Population Aging, Health Care, and Fiscal Policy Reform: The Challenges for Japan. Retrieved Agustus 29, 2020, from The Research Institute of Economy, Trade and Industry (RIETI): https://www.rieti.go.jp/ jp/publications/dp/17e038.pdf.

Morrow-Howell, N., Galucia, N., \& Swinford, E. (2020). Recovering from the COVID-19 Pandemic: A Focus on Older Adults. Journal of Aging \& Social Policy, 1-9. Retrieved Agustus 20, 2020.

Mosqueda, L., Burnight, K., Gironda, M. W., Moore, A. A., Robinson, J., \& Olsen, B. (2016). The Abuse Intervention Model: A Pragmatic Approach to Intervention for Elder Mistreatment. Journal of the American Geriatrics Society, 1879-1883. Retrieved Agustus 22, 2020.

Neumark, D., \& Button, P. (2014, April 7). Age Discrimination and the Great Recession. Retrieved Agustus 22, 2020, from Federal Reserve Bank of San Fransisco: https:// www.frbsf.org/economic-research / publications/economic-letter/2014/april/ age-discrimination-older-workers-greatrecession/.

Nursaniyah, F. (2020, April 20). Kisah Lansia Penjual Gorengan di Tengah Pandemi Corona, Berjalan 10 KM demi Sesuap Nasi. Retrieved Agustus 14, 2020, from Pikiran Rakyat: https://depok.pikiran-rakyat.com/jawabarat/pr-09369013/kisah-lansia-penjualgorengan-di-tengah-pandemi-coronaberjalan-10-km-demi-sesuap-nasi?page $=3$.

Parjono, S. (2020, Agustus 31). Bantuan Sosial PROGRES LUKemensos RI dan Pelaksanaannya di DIY. Retrieved Agustus 31, 2020, from Dinas Sosial Daerah Istimewa Yogyakarta: http://dinsos.jogjaprov.go.id/?p=7812.
Pemerintah DKI Jakarta. (2020a). Bantuan Sosial COVID-19 Tahap 2. Retrieved Agustus 20, 2020, from Jakarta Tanggap COVID-19: https://corona.jakarta.go.id/storage/ infographic/pdf/update-data-bansos-tahap2-5ec39b37c829a.pdf.

Pemerintah DKI Jakarta. (2020b). Bantuan Sosial dalam Periode Penerapan Pembatasan Sosial Berskala Besar COVID-19. Retrieved Agustus 20, 2020, from Jakarta Tanggap COVID-19: https://corona.jakarta.go.id/storage/ infographic/pdf/bantuan-sosial-dalamperiode-penerapan-psbb-5e9875f684cfd.pdf.

Pemerintah DKI Jakarta. (2020c). Jaga Lansia Terhindar COVID-19. Retrieved Agustus 20, 2020, from Jakarta Tanggap COVID-19: https://corona.jakarta.go.id/storage/ infographic/pdf/jaga-lansia-dari-COVID-195e98684b620a1.pdf.

Pemerintah DKI Jakarta. (2020d). Program Bantuan Sosial PSBB COVID-19 DKI Jakarta. Retrieved Agustus 20, 2020, from Jakarta Tanggap COVID-19: https://corona.jakarta. go.id/storage/infographic/pdf/programbantuan-sosial-5e9dca26da108.pdf.

Peraturan Pemerintah Republik Indonesia Nomor 43 Tahun 2004 Tentang Pelaksanaan Upaya Peningkatan Kesejahteraan Sosial Lanjut Usia.

Peraturan Menteri Sosial Republik Indonesia Nomor 12 Tahun 2013 Tentang Program Asistensi Lanjut Usia Terlantar.

Peraturan Menteri Sosial Republik Indonesia Nomor 12 Tahun 2013 Tentang Program Asistensi Lanjut Usia Terlantar.

Peraturan Pemerintah Republik Indonesia Nomor 43 Tahun 2004 Tentang Pelaksanaan Upaya Peningkatan Kesejahteraan Sosial Lanjut Usia.

Pusdatin Kesos. (2019, Agustus 09). Bantuan Pangan Non Tunai (BPNT) . Retrieved Agustus 20, 2020, from Pusdatin Kesos: https://pusdatin.kemsos.go.id/bantuanpangan-non-tunai-bpnt.

Ramadhan, D. N. (2020, Juni 15). 200 Lansia Terima Bantuan Tunai melalui Bank DKI. Retrieved Agustus 21, 2020, from Antara News: https://www.antaranews.com/ berita/1554832/200-lansia-terimabantuan-tunai-melalui-bank-dki.

Saraceno, C., \& Keck, W. (2010). CAN WE IDENTIFY INTERGENERATIONAL POLICYREGIMES IN EUROPE? European Societies, 675-696. 
Sekretariat Kabinet RI. (2020, April 14). Presiden Tetapkan Bencana Nonalam Penyebaran COVID-19 sebagai Bencana Nasional. Retrieved Agustus 13, 2020, from Sekretariat Kabinet Republik Indonesia: https://setkab. go.id/presiden-tetapkan-bencana-nonalampenyebaran-COVID-19-sebagai-bencananasional/.

Shin, K. A. (2013). Defamilization of Elderly Care and the Experiences of the Aged in Korea. Korean Social Sciences Review, 71-105.

Sudo, K., Kobayashi, J., Noda, S., Fukuda, Y., \& Takahashi, K. (2018). Japan's Healthcare Policy for the Elderly through the Concepts of Self-Help (Ji-jo), Mutual Aid (Go-jo), Social Solidarity Care (Kyo-jo), and Governmental Care (Ko-jo). Policy Forum BioScience Trends, 7-11. Retrieved Agustus 22, 2020.

T.Gregory, A., \& Denniss, A. R. (2018). An Introduction to Writing Narrative and Systematic Reviews - Tasks, Tips and Traps for Aspiring Authors. Heart, Lung and Circulation, 893-898. Retrieved Agustus 20, 2020.

Tim Nasional Percepatan Penanggulangan Kemiskinan. (2018, October). THE FUTURE OF THE SOCIALPROTECTION SYSTEM IN INDONESIA: SOCIAL PROTECTION FOR $A L L$. Retrieved Agustus 20, 2020, from Tim Nasional Percepatan Penanggulangan Kemiskinan: http://www.tnp2k.go.id/ download/33117200829-TNP2K\%20 The $\% 20$ Future $\% 20$ of $\% 20$ Social $\% 20$ Protection-Full\%20Report-EN.pdf.

Tsutsui, T. (2014). Implementation Process and Challenges for the Community-Based Integrated Care System in Japan. International Journal of Integrated Care, 1-9. Retrieved Agustus 25, 2020

Undang-Undang Republik Indonesia Nomor 13 Tahun 1998 Tentang Kesejahteraan Lanjut Usia
Undang-Undang Republik Indonesia Nomor 24 tahun 2007 Tentang Penanggulangan Bencana.

Undang-Undang Republik Indonesia Nomor 13 Tahun 1998 Tentang Kesejahteraan Lanjut Usia.

Undang-Undang Republik Indonesia Nomor 24 tahun 2007 Tentang Penanggulangan Bencana.

United Nations. (2020). The Impact of COVID-19 on older persons. United Nations. Retrieved from https://www.un.org/development/ desa/dspd/wp-content/uploads / sites/22/2020/05/un_policy_brief_on_ COVID-19_and_older_persons_1_may_2020. pdf.

Yanuardi, Fitriana, K. N., \& Ahdiyana, M. (2017). Evaluasi Kebijakan Sosial Peningkatan Kesejahteraan Lanjut Usia Terlantar (LUT). Jurnal Penelitian Kesejahteraan Sosial, 1-10.

Yong, V., \& Saito, Y. (2011). National Long-Term Care Insurance Policy in Japan a Decade After Implementation: Some Lessons for Aging Countries. Ageing International, 271-284. Retrieved Agustus 25, 2020.

Zahro, F. (2020, Juli 1). 2.300 Lansia Jatim yang Terdampak COVID-19 Dapat Bantuan Paket Sembako. Retrieved Agustus 24, 2020, from Surabaya Tribun News: https://surabaya. tribunnews.com/2020/07/01/2300-lansiajatim-yang-terdampak-COVID-19-dapatbantuan-paket-sembako.

Zulfikar, M. (2020, April 17). Kemensos Salurkan Bantuan bagi DisabilitasLansia terdampak COVID-19. Retrieved Agustus 25, 2020, from Antara Jateng: https://jateng.antaranews.com/nasional/ berita/1428449/kemensos-salurkanbantuan-bagi-disabilitas-lansia-terdampakCOVID-19?utm_source=antaranews\&utm $\mathrm{m}$ e d i u $\mathrm{m}=\mathrm{n}$ a s i o n a l \& u t m _ campaign=antaranews. 